\title{
In natura açaí beverage: quality, pasteurization and acidification
}

\author{
Bebida de açaí in natura: qualidade, pasteurização e acidificação
}

\author{
Palmira Antonia Alves Cruz de OLIVEIRA ${ }^{1}$, Idelfonso Generôzo da SILVA ${ }^{1}$, \\ Maria Luzenira de SOUZA ${ }^{2 *}$, Cydia Menezes FURTADO ${ }^{3}$, Reginaldo Ferreira da SILVA ${ }^{4}$
}

\begin{abstract}
The purpose of this work was to evaluate the physical, physicochemical, chemical and microbiological characteristics of in natura açai (Euterpe precatoria Mart.) beverage processed and commercialized in Rio Branco, Acre, submitting it to acidification and pasteurization treatments and evaluating their effects. Açaí fruits were processed to obtain the beverage as generally consumed. A $25 \mathrm{~L}$ sample was collected from a processing unit at a market in Rio Branco and transported to the Laboratory of Food Technology at the Federal University of Acre, for sampling of the experiments in a completely randomized design. Analyses of total solids, $\mathrm{pH}$, total titrable acidity, proteins, lipids, moulds and yeasts, total and heat-tolerant coliforms at $45^{\circ} \mathrm{C}$ were performed in in natura beverage and after treatments. The results of the ANOVA showed, except for lipids, difference $(\mathrm{p} \leq 0.01)$ in the parameters. The in natura açaí beverage presented an elevated contamination by total and heat-tolerant coliforms at $45^{\circ} \mathrm{C}$, moulds and yeasts, being in hygienic-sanitary conditions both unsatisfactory and unsafe for consumption. Pasteurization was efficient in reducing the beverage microbiota; it reduced contamination to an acceptable level according to the legislation, warranting food quality and safety. The acidified treatment partially reduced the microbiota. The beverage was classified as fine or type C. Keywords: açaí derived; conservation; analyses; food safety.
\end{abstract}

\section{Resumo}

O objetivo deste trabalho foi avaliar as características físicas, físico-químicas, químicas e microbiológicas da bebida de açaí (Euterpe precatoria Mart.) in natura, processada e comercializada em Rio Branco-Acre, submetê-la a tratamentos de acidificação e pasteurização e avaliar seus efeitos. Frutos de açaí foram processados para obtenção da bebida, conforme geralmente consumida. Uma amostra de 25 litros foi coletada de uma unidade processadora, no mercado municipal de Rio Branco, transportada ao laboratório da Unidade de Tecnologia de Alimentos da Universidade Federal do Acre para montagem de experimentos em delineamento inteiramente casualizado. Na bebida in natura e após tratamentos realizou-se as análises de sólidos totais, $\mathrm{pH}$, acidez total titulável, proteínas, lipídios, bolores e leveduras, coliformes totais e termotolerantes a $45^{\circ} \mathrm{C}$. Os resultados da ANOVA mostraram, exceto lipídios, diferença $(\mathrm{p} \leq 0,01)$ nos parâmetros. A bebida de açaí in natura apresenta elevada contaminação por coliformes totais e termotolerantes a $45^{\circ} \mathrm{C}$, bolores e leveduras, estando em condições higiênico-sanitária insatisfatória e insegura ao consumo. A pasteurização foi eficaz na redução da microbiota da bebida, reduziu a contaminação para nível aceitável, conforme a legislação, garantindo qualidade e segurança alimentar. O tratamento acidificado reduziu parcialmente a microbiota. A bebida é classificada como açaí fino ou tipo C.

Palavras-chave: derivado de açaí; conservação; analises; segurança alimentar.

\section{Introduction}

The State of Para, northern region of Brazil, stands out with $96 \%$ of the production of açaí fruits of the native species Euterpe oleracea, followed by the states of Acre, Amazonas and Amapa with only $1 \%$ each. The native extractivist production of açaí (fruit) in the State of Acre in 2007 was of 1.459 t representing an amount of R $\$ 667,000$, approximately 405 thousand litters a year being consumed (INSTITUTO..., 2007).

In Acre, the predominant açaí tree species is Euterpe precatoria, which demonstrates to be one of the plant species with a great potential of use by small household farmers, rubber gatherers and riverine populations, since the exploitation of fruits in the period of crop, contributes to compose the family income of their gatherers (BARTH; CABRAL, 2002).

Açaí fruit is very popular in the northern region and greatly utilized in the making of beverages, sweets, ice-creams and jams. According to Rogez (2000), it is one of the most nutritive fruits of the Brazilian Legal Amazon. The pulp is a source of $\alpha$-tocopherol (vitamin E), anthocyanines, fiber, manganese, copper, boron, calcium, magnesium, potassium and chrome. The protein present in the fruit can supply between 25 to $65 \%$ of the amounts recommended for good feeding. But, it is poor in total sugars, phosphorus, sodium, zinc and iron. Anthocyanines possess an antioxidant function, which assures improved blood

\footnotetext{
Received 4/10/2009

Accepted 11/2/2010 (004446)

${ }^{1}$ Agronomy/Vegetable Production, Federal University of Acre - UFAC, Rio Branco, Acre, Brasil, E-mail:palmiraoliveira@brturbo.com.br; idelfonso.generoso@ac.gov.br

${ }^{2}$ Agronomy/Vegetable Production, Federal University of Acre - UFAC, Campus Universitário, Rod. BR 364, Km 04, n. 6637, CEP 69915-900, Distrito Industrial, Rio Branco, AC, Brasil, E-mail: mluzen@hotmail.com

${ }^{3}$ Federal University of Acre - UFAC, E-mail: cydia10@gmail.com

${ }^{4}$ Researcher at Federal University of Acre - UFAC, E-mail: reginaldo.alimentos@gmail.com

${ }^{*}$ Corresponding author
} 
circulation and protects the organism against the accumulation of lipid deposition plaques, causers of atherosclerosis (COHEN, 2009).

Pereira et al. (2006), analyzing frozen fruit pulps commercialized in Viçosa, MG, found in the in natura açaí pulp, values of $\mathrm{pH}$ and total soluble solids that ranged from 4.00 to 4.61 and 1 to $2{ }^{\circ} \mathrm{Brix}$, respectively. According to the authors, some pulps were out of the physicochemical standards demanded for the specific fruits and that the açaí pulp, from the three brands analyzed; it can have been excessively diluted.

According to the Ministry of Agriculture Normative Ruling (BRASIL, 2001), the preparation of açaí with addition of water and its quantities, can be classified like: thick or special açaí (type A) - is the extracted pulp with the addition of water and filtration, presenting above $14 \%$ of total solids and very thick appearance; medium or regular açaí (type B) - is the extracted pulp with the addition of water and filtration, presenting above 11 to $14 \%$ of total solids and a thick appearance and, the slight or popular (type $\mathrm{C}$ ) is the extracted pulp with addition of water, presenting from 8 to $11 \%$ of total solids and slightly thick appearance. In this case, such products of açaí should obey the following physicochemical and chemical characteristics, with variations between minimal and maximum value for: $\mathrm{pH}-4.00$ and 6.20; total titrable acidity (TTA) expressed in g. $100 \mathrm{~g} \mathrm{~g}^{-1}$ of citric acid, with values expressed only for the maximum level. Namely, $0.27 \mathrm{~g} .100 \mathrm{~g}^{-1}$ of acidity to the fine açaí; $0.40 \mathrm{~g} .100 \mathrm{~g}^{-1}$ to the medium açaí and $0.45 \mathrm{~g} .100 \mathrm{~g}^{-1}$ of acidity to the thick açaí. Total lipids should present minimum and maximum contents of 20 and $60 \mathrm{~g} .100 \mathrm{~g}^{-1}$ of dry matter, respectively; proteins the minimum of 6 g. $100 \mathrm{~g} \mathrm{~g}^{-1}$ of dry matter and total sugars, the maximum $40 \mathrm{~g} .100 \mathrm{~g}^{-1}$ of dry matter.

However, the açaí fruit is considered of high perishability, deserving special care during the harvest and post-harvest of fruits and the processing of the beverage must obligatorily be submitted to the procedures of good extractivist, agricultural and manufacture practices, aiming to assure the beverage quality to warrant food safety to the consumer.

Recent works conducted on the commercialized pulp and juice of in natura açaí have shown the lack of application of good manufacturing practices, having an indirect influence upon the high degree of contamination. The microbiological and microscopic quality of samples of açaí pulped in beater in the state of Amapa was investigated by Sousa, Melo and Almeida (1999). The authors collected 09 samples of pulped açaí, 09 samples of the fruit and 09 samples of the water used in the making of the beverage. The results showed that $77.8 \%$ to $100 \%$ of the samples were contaminated by fecal coliforms, moulds and yeasts, presenting contamination levels greater than those established by the country's current legislation.

Analyzing the microbiological quality of pulps of frozen fruits, Pereira et al. (2006) concluded: pulps of cashew, guava and soursop (brand A); açaí and strawberry (brand B); açaí, guava and soursop (brand C) were considered inadequate for consumption for showing high amounts of filamentous fungi and yeasts.
Sousa et al. (2006) applied heat treatments of pasteurization and boiling in açaí juice at different temperatures and times and evaluated the shelf-life for a 120-day period. The microbiological results of in natura açaí demonstrated high contamination by total $\left(>1100 \mathrm{MPN} \cdot \mathrm{mL}^{-1}\right)$, fecal $\left(>110 \mathrm{MPN} \cdot \mathrm{mL}^{-1}\right)$ coliforms and moulds and yeasts $\left(>10^{4} \mathrm{CFU} \cdot \mathrm{mL}^{-1}\right)$. According to the same authors, pasteurization at $90^{\circ} \mathrm{C}$ for five minutes demonstrated efficiency in eradicating microorganisms, since they preserved the sensorial characteristics in addition to keeping the açaí juice for a 120 -day period at $-18^{\circ} \mathrm{C}$.

By token of the exposed, the present work was intended to evaluate the quality of the in natura açaí beverage commercialized in Rio Branco, AC; apply the pasteurization and acidification treatments and evaluate their effects on the physical, physicochemical, chemical and microbiological characteristics.

\section{Materials and methods}

\subsection{Raw matter and experimental assay}

The raw matter utilized was $25 \mathrm{~L}$ of in natura açaí beverage ready for consumption coming from the collection in a processing unit at a city market in Rio Branco.

$25 \mathrm{~L}$ of the newly-processed beverage were collected; at random from an açaí processing unit such as it is commercialized and consumed in Rio Branco-AC. In adequate polyethylene store, the samples were transported in isotherm boxes to the Food Technology Unit Laboratory/UTAL at UFAC. Immediately, the microbiological and physical, physicochemical and chemical analyses were started in the in natura açaí beverage.

The experimental assays conducted were: check/control $\left(T_{1}\right)$ - in natura açaí beverage; $\left(T_{2}\right)$ in natura beverage with the addition of $1 \%$ lemon juice; $\left(\mathrm{T}_{3}\right)$ in natura beverage with the addition of $2 \%$ lemon juice. For each of the assays, $\mathrm{T}_{2}$ and $\mathrm{T}_{3}$ one litter of açaí beverage was utilized, adding unmixed lemon juice, homogenizing for five minutes to enable the interaction of citric acid with the components of the açaí beverage. $\left(\mathrm{T}_{4}\right)$ beverage pasteurized at $80^{\circ} \mathrm{C}$ in water bath, under shaking, for two minutes; $\left(\mathrm{T}_{5}\right)$ beverage pasteurized at $90{ }^{\circ} \mathrm{C}$ in water bath under shaking, for two minutes for even heat distribution. Treatments $\mathrm{T}_{4}$ and $\mathrm{T}_{5}$, after pasteurization, were submitted, under constant shaking, to thermal shock in water with ice for even cooling. All the assays were performed in four replicates, from each treatment and plot (replicate). The following physical, physicochemical, chemical and microbiological analyses were conducted.

\section{$2.2 p H$}

The value of $\mathrm{pH}$ was obtained through the direct reading in electron potentiometer, mark Tecnal, model Tec-3MP utilizing five grams of the beverage diluted in $50 \mathrm{~mL}$ of distilled water.

\subsection{Titrable total acidity}

Total titrable acidity (TTA) was determined by titration, with a solution of $0.1 \mathrm{~N} \mathrm{NaOH}$ and $1 \%$ phenolphthalein 
as indicator and the values were expressed in percentages of citric acid according to the Analytical Standards of LLC (INSTITUTO..., 2008).

\subsection{Protein}

The content of total nitrogen of the sample was determined by the Kjeldahl procedure according to the methodology of the Association of Official Analytical Chemists - AOAC (1995), utilizing the factor 5.75 for conversion of nitrogen into protein.

\subsection{Lipids}

Lipid was determined by utilizing the Soxhlet extractor, according to the methodology of the Association of Official Analytical Chemists - AOAC (1995), method 945.38, by extraction with the organic solvent, petroleum ether, followed by the removal, through evaporation.

\subsection{Moulds and yeasts}

For the preparation of the sample, two portions of $25 \mathrm{~mL}$ of each sample of the açaí beverage were utilized aseptically, which were homogenized with $225 \mathrm{~mL}$ of $0.1 \%$, sterile peptoned water, dilution $10^{-1}$. From this, successive decimal dilutions were performed in the same diluent $\left(10^{-2}\right.$ to $\left.10^{-3}\right)$, to use in all the determinations (SILVA et al., 2007).

To determine moulds and yeasts, the aerobic count plate technique, utilizing Agar Dichloran Rose-Bengal Cloramphenicol (DRBC) and incubation at $22-25{ }^{\circ} \mathrm{C}$ for 5 days was used. The results were expressed in colony-forming units-CFU.mL $\mathrm{mL}^{-1}$.

\subsection{Total and coliforms and heat-tolerant at $45^{\circ} \mathrm{C}$}

The multiple tube fermentation technique with three series of three tubes for each dilution $\left(10^{-1}, 10^{-2}, 10^{-3}\right)$ was used. As a presumptive means, lauryl sulfate tryptose broth with incubation at $35{ }^{\circ} \mathrm{C}$ for 48 hours was employed. In the confirmatory test, $2 \%$ brilliant green lactose bile broth for total coliforms with incubation at 35 at $35{ }^{\circ} \mathrm{C}$ for $24-48$ hours and EC broth for heat-tolerant (fecal) coliforms with incubation at $44.5{ }^{\circ} \mathrm{C}$ in water bath for 24 hours were utilized. The most probable number-MPN/mL $\mathrm{mL}^{-1}$ of total and heat-tolerant coliforms at $45^{\circ} \mathrm{C}$ was determined with the aid of the Hoskins table, from the number of positive tubes of the different dilutions employed (SILVA et al., 2007).

\subsection{Statistical analysis}

The statistical design used was the completely randomized one, with five treatments and four replicates. The control treatment $\left(\mathrm{T}_{1}\right)$ in natura açaí beverage $\left(\mathrm{T}_{2}\right)$ in natura beverage acidified at 1\%; $\left(\mathrm{T}_{3}\right)$ in natura beverage acidified at $2 \% ;\left(\mathrm{T}_{4}\right)$ beverage pasteurized at $80^{\circ} \mathrm{C}$ in water bath for two minutes and $\left(\mathrm{T}_{5}\right)$ beverage pasteurized at $90^{\circ} \mathrm{C}$ in water bath for two minutes. The results of the physical, physicochemical and microbiological characteristics were submitted to the analysis of variance, $F$ test, coefficient of variation and Scott-Knott test at $5 \%$ of probability (FERREIRA, 2000).

\section{Results and discussion}

The results of the physical, physicochemical and chemical analyses obtained are presented in Table 1. It is found that with the exception of lipid content, acidification and pasteurization influenced significantly the physicochemical components of the açaí beverage in relation to the check $\left(\mathrm{T}_{1}\right)$.

\section{$3.1 \mathrm{pH}$ and titrable total acidity}

The in natura beverage presented $\mathrm{pH} 4.30$, with no any difference from the ones treated by pasteurization. Those treated with 1 and $2 \%$ of lemon juice presented the lowest values $\mathrm{pH}$ 4.07 and 4.00 , respectively. The decrease of the $\mathrm{pH}$ values of the acidified treatments occurred due to the rise of acidity, in citric acid due to the addition of lemon juice (Table 1). Barbosa (2009) analyzing in natura açaí beverage coming from the state of Acre, found average $\mathrm{pH}$ value in the range of 4.51 close to that found in this work.

Barth and Cabral (2002) and Tonon, Barbet and Hubinger (2009) analyzing the physicochemical composition of the açaí beverage, report average $\mathrm{pH}$ values of 5.03 and 5.18, greater than those of the present study. In spite of finding different $\mathrm{pH}$ values between the average value of that found in this study and other values reported in the literature, all the $\mathrm{pH}$ values reported are within the minimal and maximal range reported in the legislation, that is, 4.0 to 6.20 and, therefore, in compliance with the standards established by the Ministry of Agriculture and Supply (BRASIL, 2001).

Table 1. Mediums values of the characteristics physical, physicochemical and chemical of the in natura açaí beverage, acidified and pasteurized.

\begin{tabular}{|c|c|c|c|c|c|}
\hline \multirow[t]{2}{*}{ Treatments } & \multicolumn{5}{|c|}{ Characteristics of in natura açaí beverage } \\
\hline & $\begin{array}{c}\mathrm{ST} \\
\left(\mathrm{g} .100 \mathrm{~g}^{-1}\right)\end{array}$ & $\begin{array}{c}\text { ATT } \\
\text { (\% Citric acid) }\end{array}$ & $\begin{array}{l}\text { Proteins } \\
\left(\mathrm{g} .100 \mathrm{~g}^{-1}\right)\end{array}$ & $\mathrm{pH}$ & Lipids (g.100 $\mathrm{g}^{-1}$ ) \\
\hline $\mathrm{T}_{1}$ - Check in natura & $10.35^{\mathrm{d}}$ & $0.53^{c}$ & $9.45^{c}$ & $4.30^{\mathrm{a}}$ & $31.07^{\mathrm{a}}$ \\
\hline $\mathrm{T}_{2}-1 \%$ Acidified & $11.24^{\mathrm{b}}$ & $0.62^{\mathrm{b}}$ & $8.64^{\mathrm{d}}$ & $4.07^{\mathrm{b}}$ & $30.77^{\mathrm{a}}$ \\
\hline $\mathrm{T}_{3}-2 \%$ Acidified & $10.84^{\mathrm{c}}$ & $0.91^{\mathrm{a}}$ & $12.29^{\mathrm{a}}$ & $4.00^{\mathrm{b}}$ & $30.02^{\mathrm{a}}$ \\
\hline $\mathrm{T}_{4}-$ Pasteurized $\left(80^{\circ} \mathrm{C} / 2\right.$ minutes $)$ & $10.21^{\mathrm{d}}$ & $0.30^{\mathrm{d}}$ & $10.51^{b}$ & $4.31^{\mathrm{a}}$ & $30.45^{\mathrm{a}}$ \\
\hline $\mathrm{T}_{5}$ - Pasteurized ( $90^{\circ} \mathrm{C} / 2$ minutes) & $12.02^{\mathrm{a}}$ & $0.28^{\mathrm{e}}$ & $8.87^{\mathrm{d}}$ & $4.40^{\mathrm{a}}$ & $30.09^{\mathrm{a}}$ \\
\hline MG & 10.93 & 0.1399 & 9.95 & 4.21 & 30.28 \\
\hline $\mathrm{CV}(\%)$ & 4.17 & 17.42 & 14.40 & 1.35 & 3.07 \\
\hline
\end{tabular}

Means followed by the same letter in the column do not diff statically from each other at the level of $5 \%$ of probability by the Scott Knoot test; TS = Total solids or DM = dry matter; \%ATT - TTA total titrabale acidity ; GM = General mean; CV = Coefficient of variation 
The values of total titrable acidity - TTA in citric acid in the treatments added with 1 and $2 \%$ of lemon juice and of the in natura açaí beverage outstood with an average value of $0.62,0.91$ and 0.53 g. $100 \mathrm{~g}^{-1}$, respectively - results higher than the general mean of the other treatments. This parameter is in disagreement with the maximal content of acidity established by the legislation of MAPA, maximum 0.27 and $0.40 \mathrm{~g} .100 \mathrm{~g}^{-1}$ for açaí classified as fine and medium, respectively. But, the same legislation admits the addition of acid in the açaí beverage as the only permitted additive.

The option of acidifying the beverage with lemon juice, rich in citric acid, aimed to lower the $\mathrm{pH}$ of the beverage, making the beverage unviable and the growth of health-dangerous and decaying microbiota difficult; also, because of the facility in obtaining and utilizing citric acid through lemon fruits by family farmers; and because of the results obtained by Carneiro (2000), who cites the reduction of $\mathrm{pH}$ by the addition of citric acid in the açaí beverage, warranting a microbiologically stable product.

In this work, the high acidity content observed in the in natura açaí beverage is due, in part, to the early high contamination rate observed through the microbiological analyses, where it was impossible to make the counting of the colonies present on Petri dish and the total positivity of coliforms in the multiple tubes. However, the pasteurization process impacted significantly the decreased acidity of the samples treated by this method, leaving them within the safe limit of feeding.

Tonon, Barbet and Hubinger (2009) found medium value of acidity in $0.34 \%$ citric acid in the açaí pulp coming from BelémPA. Barbosa (2009) studied three brands of açaí pulp coming from Acre and found acidity values in citric acid between 0.49 to $0.52 \mathrm{~g} .100 \mathrm{~g}^{-1}$, the same ones being in disagreement with the legislation. Pacheco Junior (2007), working on açaí processed in Rio Branco, obtained results of total acidity in citric acid with a high variation rate, between 0.10 and $0.65 \%$.

Citric acid is one of the most abundant organic acids in fruits, it is highly important, due to its influence in the sensorial characteritics of foods such as color, flavor, aroma, stability as well as in the keeping quality. In general, the proportion of organic acids present in fruits and vegetables ranges according to the maturation degree and growth conditions of the plant.

Chitarra and Chitarra (2006) emphasize that citric acid presents antimicrobial capacity due to the chelating capacity of metals and it is used as an additive for preventing enzymaatic browning and for potentiating other antioxidants (synergistic action), like ascaorbic acid.

\subsection{Protein}

The average protein content of the in natura açaí beverage was of $9.95 \mathrm{~g} .100 \mathrm{~g} \mathrm{~g}^{-1}$, it presents differences between the other treatments, with the acidified one standing out at $2 \%$, with $12.29 \%$, according to Table 1 . This difference must be owed to the inadequate homogenization of the samples from where the assays were obtained. To corroborate with these results, in the literature, a protein value of $8.51{\mathrm{~g} .100 \mathrm{~g}^{-1} \text { was }}$ found by Barth and Cabral (2002) when analyzing the açaí beverage coming from the state of Acre and data expressed by Brasil (1998) with $9.40 \mathrm{~g} .100 \mathrm{~g}^{-1}$ of protein, all close to those found in the present study.

Tonon, Barbet and Hubinger (2009) reported average value of $1.43 \%$ of protein in the native pulp of açaí from Belem-PA. Barbosa (2009) observed a variation in the average contents of protein in the açaí beverage going from 8.33 to $10.33 \mathrm{~g} .100 \mathrm{~g}^{-1}$ for medium type açaí. However, a value close to that observed in the present work, $10.05 \mathrm{~g} .100 \mathrm{~g} \mathrm{~g}^{-1}$, was found by Rogez (2000) in açaí pulps commercialized in the State of Para.

On the basis of the Normative Ruling n 01, Jan 17, 2000 (BRASIL, 2000), which establishes the Identity and Quality Standards for açaí pulp (thick, medium and slight); the minimum content of proteins that must be present in $100 \mathrm{~g}$ of sample is $6 \mathrm{~g} \cdot 100 \mathrm{~g} \mathrm{~g}^{-1}$. Therefore, all the samples of açaí beverage investigated in this study were above those established by the cited legislation.

\subsection{Lipids}

In spite of no significant difference has been found ( $p \leq 0.01$ ) for the lipids contents in the in natura açaí beverage among the other treatments, the average value of $30.28 \mathrm{~g} .100 \mathrm{~g} \mathrm{~g}^{-1}$, is in agreement with the Brazilian legislation, which demands minimum and maximum values of 20 and $60 \mathrm{~g} .100 \mathrm{~g}^{-1}$ of dry matter (Table 1).

Barth and Cabral (2002) analyzed açaí beverage coming from fruits of the species Euterpe precatoria Martins, found an average value of $24.65 \mathrm{~g} .100 \mathrm{~g}^{-1}$ of lipid. But, Barbosa (2009) cited lipid values ranging from 23.33 to $25.33 \mathrm{~g} .100 \mathrm{~g}^{-1}$ for the medium-type açaí.

Tonon, Barbet and Hubinger (2009) reported an average value of $6.83 \%$ of lipid in the pulp of açaí coming from Belem$\mathrm{PA}$, a value quite bellow those found in this work and those reported by Barth and Cabral (2003) and Barbosa (2009), who also studied the product obtained from the state of Acre. Surely, this is due to the species Euterpe precatoria in abundance in Acre, from which the beverage is obtained (in the State of Para, the common species is Euterpe oleraceae) and to the highest water content added for pulp extraction. However, the difference in chemical composition between a same product is common and depends on a great deal of variables such as species, harvest season, collection and/or extraction, maturation stage, genetic variability, edaphic-climatic, pluviometric factors, altitude and among others.

\subsection{Total solids or dry matter}

Comparing the values of dry matter (DM) or total solids (TS), between the treatments, significant variations $(\mathrm{p}<0,01)$ were observed through the Scott-Knott test (FERREIRA, 2000 ), pointing out that the treatments pasteurized at $90{ }^{\circ} \mathrm{C}$ for 2 minutes and the one acidified with $1 \%$ of lemon juice, presented the highest values, 12.02 and $11.24 \mathrm{~g} .100 \mathrm{~g}^{-1}$, respectively. That difference may possibly be a result of the inadequate homogenization of the sample from which the assays were obtained and from the pasteurization process, 
which involves water loss of the beverage through evaporation, enabling the concentration of the total solid content.

The values of total solids or dry matter found in the in natura sample acidified at $2 \%$ and pasteurization at $80^{\circ} \mathrm{C}$, allow to classify them as fine or popular C-type beverage, because they present average contents of total solids of $10.35 \%, 10.84 \%$ and $10.21 \%$, respectively. However, the samples treated by pasteurization at $90^{\circ} \mathrm{C}$ for 2 minutes and the one acidified at $1 \%$ can be classified as medium-type or regular beverages for showing average total solids contents of $12.02 \%$ and $11.24 \%$, according to Brazilian legislation. This result must be caused by inadequate homogenization of the sample from where the assays were obtained.

\subsection{Total coliforms, heat-tolerant at $45^{\circ} \mathrm{C}$ and yeast moulds}

Açaí degrades a few hours after collection/harvest, even under refrigeration. The reasons for that high perishability is the great microbial load and enzyme systems present both in the fruit and the pulp, which interfere in the characteristics and quality of the derived product, after processing. To decrease or eliminate the microbiological problem, it is obligatory to apply adequate operational procedures in light of the legislation, involving hygiene in all the steps of the productive chain, in the good extractivist, agricultural and manufacturing practices during the processing of açaí derived-products.

Detecting the presence of microorganisms in the açaí beverage, accounts for the need to apply adequate hygienic-sanitary procedures, such as quality control measures in all the processes of the productive chain, since the gathering and/or cultivation, harvest, handling, transport, storage, improvement and/or processing and commercialization. Such control and care measures enable the obtainment of a high quality product, safe and adequate for human feeding and health.

In Table 2, the microbiological results of the in natura açaí beverage processed and commercialized in Rio Branco-AC present high contamination by total coliforms and heat tolerant at $45{ }^{\circ} \mathrm{C}\left(>1100 \mathrm{MPN} \cdot \mathrm{mL}^{-1}\right)$, in addition to uncountable values of moulds and yeasts, all above the limits of microbiological sanitary standards for foods established by Resolution RDC number 12 (BRASIL, 2001). This condition shows serious failures of hygienics and handling in the procedures and practices: extractivist, collection, transport, hygienic and manufacturing to which the fruits were submitted, generating food insecurity and consumers' health danger.
Costa and Costa (2002) evaluating the quality of açaí beverage (Euterpe precatoria Mart.) commercialized at the market in Rio Branco-AC, cited values of microbiological contamination close to those found in the present study. The authors found that in $100 \%$ of the samples investigated, total and heat tolerant at 45 with values $>1100 \mathrm{MPN} \cdot \mathrm{mL}^{-1}$. The values of moulds and yeasts found were also high in all the samples ranging from $1.5 \times 10^{3}$ to $7.3 \times 10^{5} \mathrm{CFU} \cdot \mathrm{mL}^{-1}$.

Analyzing samples of in natura açaí beverage commercialized in three fairs in Manaus-AM, Sousa et al. (2006) also found high contamination by total and fecal coliforms, moulds and yeasts, corroborating with the results of this work.

The pasteurization treatments, $\mathrm{T}_{4}$ and $\mathrm{T}_{5}$ demonstrated efficient reduction of the early microbial load present in the in natura açaí beverage, being able to be recommended for consumption, warranting food safety. The early contamination of fecal and heat tolerant at $45^{\circ} \mathrm{C}$, which was $>1100 \mathrm{MPN} \cdot \mathrm{mL}^{-1}$ in the in natura beverage, decreased to $<3 \mathrm{MPN} \cdot \mathrm{mL}^{-1}$ after the pasteurization process. CFU.mL $\mathrm{m}^{-1}$ of moulds and yeasts, which presented themselves at first as uncountable, decreased to $1.4 \times 10^{2}$ (Table 2) in the pasteurized treatment $\mathrm{T}_{5}$.

Sousa et al. (2006) also suggested that açaí beverage be submitted to the pasteurization process at $90^{\circ} \mathrm{C}$ for 10 minutes as a way to decrease the high contamination rate that the açaí pulp presents. However, according to the author, the boiling process, despite having shown greater efficiency than pasteurization is not recommended, even for a short time period ( 1 minute), for influencing negatively the sensorial characteristics of the beverage.

In general, fruit-derived foods are submitted to the thermal process of pasteurization before commercialization. This assures the maintenance of quality and food safety, since the decaying and pathogenic microbiota and other factors are destroyed and/or made inactive by heat. In this case, the processed açai beverage needs to be pasteurized to guarantee food safety and quality maintenance.

In relation of the thermal treatment, the greater the time-temperature binomial of any thermal process, followed by fast cooling in iced water, the greater will be the efficiency of the process and the poorer will be the microbial load remaining in the food. However, Silva et al. (2007) warns that time and temperature cannot be raised indiscriminately, because they will endanger the nutritional and sensorial quality of the product.

The use of natural citric acid (lemon juice) in percents of 1 and $2 \%$, added into the in natura açaí beverage was intended

Table 2. Results of the microbiological analyses of the in natura açaí beverage treated by acidification and pasteurization.

\begin{tabular}{lccc}
\hline \multicolumn{1}{c}{ Treatments } & $\begin{array}{c}\text { Total coliforms } \\
{ }^{*} \mathrm{MPN}_{\mathrm{mL}}{ }^{-1}\end{array}$ & $\begin{array}{r}\text { Heat-tolerant coliforms at } 45^{\circ} \mathrm{C} \\
{ }^{*} \mathrm{MPN}_{\mathrm{mL}} \mathrm{mL}^{-1}\end{array}$ & $\begin{array}{c}\text { Moulds and yeasts } \\
{ }^{* *} \mathrm{CFU} . \mathrm{mL}^{-1}\end{array}$ \\
\hline $\mathrm{T}_{1}$-Check (in natura) & $>1100$ & $>1100$ & Uncountable \\
$\mathrm{T}_{2}-1 \%$ Acidified & $>1100$ & $>460$ & $1.4 \times 10^{3}$ \\
$\mathrm{~T}_{3}-2 \%$ Acidified & $>150$ & $>93$ & $8.3 \times 10^{2}$ \\
$\mathrm{~T}_{4}$-Pasteurized at $80^{\circ} \mathrm{C} / 2^{\prime}$ & $<3$ & $<3$ & $2.4 \times 10^{2}$ \\
$\mathrm{~T}_{5}$-Pasteurized at $90^{\circ} \mathrm{C} / 2^{\prime}$ & $<3$ & $<3$ & $1.4 \times 10^{2}$ \\
\hline
\end{tabular}

${ }^{\star} \mathrm{MPN}=$ most probable number $;{ }^{* *} \mathrm{CFU}=$ colony forming units 
to verify the effect of the concentration on the microbiological characteristics of the product. Nevertheless, it was found that the same one reduced the microbiota, but, it was not effective in reducing the early microbial load, to the extent to make the product both suitable and safe for human consumption, within the standards of the legislation. So, further studies on the subject are suggested as well as the comparison with commercial citric acid, for its being in the isolated and more concentrate active form.

\section{Conclusions}

The in natura açaí beverage presents high contamination by total coliforms and heat-tolerant at $45^{\circ} \mathrm{C}$, moulds and yeasts, being in hygienic-sanitary conditions unsatisfactory and dangerous for consumption.

Pasteurization at 80 and $90^{\circ} \mathrm{C}$ for two minutes was effective in reducing the early microbiota of the beverage, reducing the contamination to an acceptable level as for the Brazilian legislation, warranting the quality and food safety.

The treatment acidified at 1 and $2 \%$ reduced partially the microbiota, not consisting total efficacy to lower it to acceptable levels.

The açaí beverage analyzed in this study fits into the slight or popular type $\mathrm{C}$ standard established by MAPA.

\section{References}

ASSOCIATION OF OFFICIAL ANALYTICAL CHEMISTS - AOAC. Oficial methods of analysis of the analytical chemists. 17th ed. Washington: AOAC, 1995.

BARBOSA, J. Q. Parâmetro de qualidade da bebida açaí processada e consumida em Rio Branco - AC. 2009. 40 f. Trabalho de Conclusão de Curso (Graduação em Engenharia Agronômica)-Universidade Federal do Acre, Rio Branco, 2009.

BARTH, E.; CABRAL, W. G. Composição química do açaí (Euterpe precatoria Mart.). 2002. 40 f. Monografia (Especialização em Tecnologia de Alimentos)-Universidade Federal do Acre, Rio Branco, 2002.

BRASIL. Ministério do Meio Ambiente, dos Recursos Hídricos e da Amazônia Legal. Açaí: Produtos potenciais da Amazônia. Brasília: MMA/SUFRAMA/SEBRAE/GTA, 1998. 51 p.

BRASIL. Ministério da Agricultura Pecuária e Abastecimento. Instrução Normativa $n^{\circ} 1$, de 07 de janeiro de 2000, do Ministério da Agricultura e Abastecimento. Regulamento Técnico Geral para fixação dos Padrões de Identidade e Qualidade para polpa de fruta. Diário Oficial da República Federativa do Brasil, Brasília, DF, 10 jan. 2000. Seção 1, p. 54.

BRASIL. Ministério da Saúde do Brasil. Agência Nacional de Vigilância Sanitária. Resolução RDC n. 12, de 02 de janeiro de 2001. Aprova regulamento técnico sobre padrões microbiológicos para alimentos. Diário Oficial da República Federativa do Brasil, Brasília, DF, 10 jan. 2001. Seção 1, p. 45-53.
CARNEIRO, F. R. B. Uso da tecnologia de barreiras na obtenção da polpa de açaí e sua caracterização reológica. 2000. $161 \mathrm{f}$. Dissertação (Mestrado em Engenharia de Alimentos)- Universidade Estadual de Campinas, Campinas, 2000.

CHITARRA, M. I. F; CHITARRA, A. B. Pós-colheita de frutos e hortaliças: Fisiologia e Manuseio. Lavras: ESAL/FAEPE, 1990. $320 \mathrm{p}$.

COHEN, K. O. Sistema de Produção do Açaí: composição química do Açaí. Belém: Embrapa Amazônia Oriental, 2006. Disponível em: <http://sistemasdeproducao.cnptia.embrapa.br/FontesHTML/ Acai/SistemaProducaoAcai_2ed/paginas/composicao.htm $>$. Acesso em: 08 abr. 2009.

COSTA, L. B. M.; COSTA, S. H. L. Avaliação da qualidade microbiológica da bebida de açaí (Euterpe precatória Mart.) comercializada na cidade de Rio Branco-AC. 2002. $59 \mathrm{f}$. Monografia (Especialização em Tecnologia de Alimentos)Universidade Federal do Acre, Rio Branco, 2002.

FERREIRA, D. S. Sisvar - Sistema de análises de variância para dados balanceados: Programa de análises estatísticas e planejamento de experimentos. Versão 4.3. Lavras: UFLA, 2000.

INSTITUTO ADOLFO LUTZ. Normas analíticas do Instituto Adolfo Lutz: Métodos físico-químicos para análises de alimentos. 4. ed. São Paulo: Instituto Adolfo Lutz, 2008. 1002 p.

INSTITUTO BRASILEIRO DE GEOGRAFIA E ESTATÍSTICA - IBGE. Produção da Extração vegetal e silvicultura. Rio de janeiro: IBGE, 2008. Disponível em: <http://www.ibge.gov.br/estadosat/temas.ph $\mathrm{p}$ ? sigla $=$ ac\&tema $=$ extracaovegetal2007 $>$. Acesso em: 8 jul. 2009.

PACHECO JUNIOR, F. Avaliação de parâmetros físico-químico e higiênico-sanitário da bebida açaí processada e consumida em Rio Branco - Ac. 2007. In: SEMINÁRIO DE INICIAÇÃO CIENTIFICA DA UNIVERSIDADE FEDERAL DO ACRE/CNPq, 15., 2007, Rio Branco. Anais... Rio Branco: UFAC, 2007. 18 p.

PEREIRA, J. M. A.T. K. et al. Avaliação da qualidade físico-química, microbiológica e microscópica de polpas de frutas congeladas comercializadas na cidade de viçosa-MG. Alimentos e Nutrição, v. 17, n. 4, p. 437-442, 2006.

ROGEZ, H. Açaí: preparo, composição e melhoramento da conservação. Belém: EDUFPA, 2000. 313 p.

SILVA, N. et al. Manual de métodos de análises microbiológica de alimentos. 3. ed. São Paulo: Varela, 2007. 552 p.

SOUSA, C. L; MELO, G. M. C; ALMEIDA, S. C. S. Avaliação da qualidade do açaí (euterpe oleracea, mart.) comercializado na cidade de Macapá - AP. Boletim CEPPA, v. 17, n. 2, p. 127-136, 1999.

SOUSA, M. A. C. et al. Suco de açaí (Euterpe oleracea Mart.): avaliação microbiológica, tratamento térmico e vida de prateleira. Acta Amazonica, Manaus, v. 36, n. 4, p. 497-501, 2006. http://dx.doi. org/10.1590/S0044-59672006000400010

TONON, R. V.; BARBET, C.; HUBINGER, M. D. Influencia do ar de secagem e da concentração de agente carreador sobre as propriedades físico-químicas do suco de açaí em pó. Ciência e Tecnologia de Alimentos, v. 29, n. 2, p. 444-450, 2009. http://dx.doi.org/10.1590/S0101-20612009000200034 